\title{
Parathion-Residue Studies on Acerola
}

\author{
Julián Roldain ${ }^{1}$
}

\section{INTRODUCTION}

The economic value of using chemicals for controlling pests so as to assure good crop production has not yet been determined in Puerto Rico. Nevertheless farmers are continually searching for new chemicals for pest control. New chemicals which are far better than those used in years past are continually introduced, and with their introduction new problems have arisen, such as disposal of persisting poisonous residues. Besides making food unfit for human consumption, the indirect effect of the residues in producing off-flavors makes the problem still more difficult to solve.

\section{RESIDUAL ACTION OF PESTICIDES}

After plants are sprayed with an insecticide, this initial chemical deposit ceases to be such as soon as air, light, rain, or weathering affect it $(5)^{2}$. Once the deposit has been made, part of it sloughs off and is wasted. Some adheres to the plant parts and remains there, but some may penetrate into the plant. The insecticide that enters the plant parts is not easily recognizable after it is released by the plant. Thus, to determine the residual action of an insecticide there is need to study its vapor pressure, sticking power, solubility, and absorption into the surface on which it is applied, as well as resistance to chemical change (4).

The ideal insecticide should have enough residual action to protect the crop, but should also decompose to inert material as soon as the need for protection ends.

\section{MODE OF ACTION AND CHEMISTRY OF PARATHION}

Parathion (O,0-diethyl-O-p-nitrophenyl thiophosphate) is a high-boiling deep-brown to yellow liquid with a specific gravity of 1.26 . It is slightly soluble in water and in petroleum ether, but is completely miscible with acetone, ethyl ether, alcohols, esters, and animal or vegetable oils. It is hydrolyzed in the presence of alkaline materials such as lime, lime-sulfur, and bordeaux mixture. Parathion is prepared by having phosphorous thiotrichloride react with sodium ethoxide and the product with sodium paranitrophenate. The high toxicity of Parathion is associated with the presence of the $\left(\mathrm{C}_{2} \mathrm{H}_{6} \mathrm{O}\right)_{2} \mathrm{P}$-group $(6,8)$.

1 Assistant Chemist, Agricultural Experiment Station, University of Puerto Rico, Rio Piedras, P.R. The author wishes to express his sincere gratitude to Mario Pérez Escolar, Assistant Entomologist, for his valuable help during this investigation.

2 Italic numbers in parentheses refer to Literature Cited, p. 151. 
The chemical acetylcholine, acetylethanol trimethyl ammonium hydroxide, is a derivative of choline and is regarded as important in the mechanism of nerve action. It is believed to be produced in the nerve fibers and to help in the transmission of nerve impulses $(3,7)$. The enzyme cholinesterase hydrolyzes acetylcholine into inactive choline and acetic acid, thus preventing body accumulation of acetylcholine. If Parathion is present it will poison the enzyme cholinesterase and the acetylcholine will accumulate, thus causing uncoordinated nervous activity throughout an entire animal, and resulting in its death.

In the determination of Parathion use is made of a method developed by Bratton and Marshall (2) for the determination of sulfanilamide in blood and urine. In this method the sulfanilamide is diazotized and then coupled with $\mathrm{N}$ (1 naphtyl) ethylenediamine dihydrochloride. Averell and Norris (1) reduced the nitro group to an amino group in an acid medium. The amino group is then diazotized with sodium nitrite and then coupled with $N$ (1 naphtyl) ethylenediamine dihydrochloride. The reaction in steps is:<smiles>[H][Y10]1ccc(OP(=S)(OCC)OCC)c(OP(=S)(OCC)OCC)c1</smiles><smiles>CCOP(=S)(OCC)Oc1ccc(NN=N)cc1</smiles><smiles></smiles><smiles>CCOP(=S)(OCC)Oc1ccc(/N=N\c2ccc(NC)c3ccccc23)cc1</smiles>

\section{MATERIALS AND METHODS}

A 5-year-old grove of B. 17 variety of West Indian cherry was selected for an experiment at the Isabela Substation. The design of the experiment was a balanced incomplete block with four treatments replicated six times. 
Each replicate included four trees. Buffer rows were left between plots to reduce contamination during spray applications. The treatments given for the first experiment were as follows:

1. 3 sprays divided as follows:

A. 1 spray at blossom time

B. A second spray 10 days after

C. A third spray 10 days after the second

2. 1 spray at blossom time

3. 2 sprays divided as follows:

A. 1 spray 10 days after blossom time

B. A second spray 10 days after the first

4. Untreated check

Parathion was applied as a wettable powder at the rate of 1.5 pounds of the 15-percent formulation in 100 gallons of water. Each tree received 2.6 gallons of the spray per application with a power-motor sprayer. To prevent drifting as much as possible the trees were sprayed starting early in the morning using a canvas to protect one plot from the other.

Although precautions were taken to avoid drifting caused by the wind, it was never possible to obtain complete control.

The spray applied per tree can be estimated only approximately, for there was no control of the rate of flow of the Parathion solution or of the time factor. Another factor was that the man handling the sprayer never moved at a constant speed while spraying.

\section{SAMPLING}

Precautions were taken while the sampling was done, for contamination was easy. Therefore, those doing the sampling were required to wash their hands once they had finished sampling the corresponding plot. Four men did the sampling to assure samples as representative as possible. Two of the men went around the tree clockwise while the other two went counterclockwise. Care was taken that they took fruit from all parts of the trees. Fruits that were too ripe were not picked, for West Indian cherries are very perishable. If the fruits selected were too ripe they were dripping juice by the time they reached the laboratory. This was avoided so that the analyses were not spoiled.

\section{EXTRACTION TECHNIQUES}

Five hundred grams of whole cherries were weighed and mixed with 500 $\mathrm{ml}$. of the extracting solvent, benzene. Both cherries and solvent were placed in a steel container $71 / 8$ " wide and $81 / 2$ " long. The mouth of the steel container was covered with plastic cloth, the commercial name of which was "Clear Shelene", and the containers were placed in a shaking-machine 
and shaken end-to-end at a speed of 8.5 revolutions per minute during 1 hour. Aliquots were taken from the filtered extracted solution and analyzed for Parathion. This method of extraction was discarded because it did not accomplish the objective of the experiment.

A second extraction method was tried. In this the cherries were ground in a Waring Blendor. Two hundred and fifty grams of the pulp were mixed with $200 \mathrm{gm}$. of benzene, and the mixture was placed in a separatory funnel. The mixture was shaken occasionally for 30 minutes and an emulsion was formed. Because of this it was impossible to separate the pulp from the extracting solvent, so the method was discarded.

In a third extraction method the cherries were ground in a Waring Blendor. Two hundred and fifty grams of the pulp were placed in a stainless steel container. To this were added $200 \mathrm{gm}$. of benzene and the mixture was shaken end to end for 1 hour in a shaking-machine. The benzene extract

Table 1.-Mean content of Parathion in pulp of West Indian cherries picked after spraying 1 to $s$ times

\begin{tabular}{c|c|c}
\hline Treatment & Parathion & Time after last application \\
\cline { 2 - 3 } & $(P . p . m)$. & Days \\
3 sprays & 0.093 & 4 \\
1 spray & - & 20 \\
2 sprays & .050 & 4 \\
\hline
\end{tabular}

remained as a supernatant liquid and the pulp was easily decanted. This proved to be the best extraction technique.

\section{RESULTS}

On September 3, 1957, samples of whole cherries were taken before they were sprayed for a third time. The results of the analyses indicated that there was no Parathion present on the cherries 11 days and 21 days after they had been sprayed.

The experiment was repeated on October 18, 1957. Spray was applied on that date and two additional sprays on October 29 and November 4, respectively. Fruit samples were taken for analysis on November 7. Samples were ground in a Waring Blendor and the pulp was extracted with benzene. The extracts analyzed showed a very low content of Parathion as shown in table 1.

\section{SUMMARY}

This paper reports the results obtained in studies carried out with spray deposits left by the insecticide Parathion on West Indian cherries. Although data are not final, it seems that Parathion applied at the rate of 1.5 pounds 
per 100 gallons of water per acre to West Indian cherries leaves a residue which is below the limit established for fruits by the Food and Drug Administration of the U.S. Department of Health, Education, and Welfare.

The results thus far obtained indicate that Parathion is rapidly degraded under the conditions of these experiments. It seems too early to make any final recommendations. More experiments have to be performed, especially during other seasons of the year, so that results can be compared and critically evaluated.

\section{RESUMEN}

Se presentan los resultados obtenidos en estudios hechos con el insecticida Paración. Los resultados demuestran que el Paración aplicado a árboles de acerola, a razón de 1.5 libras en cien galones de agua por acre, dejan un residuo por debajo de los límites establecidos por el Negociado de Alimentos y Drogas del Departamento de Agricultura Federal.

\section{LITERATURE CITED}

1. Averell, P. R., and Norris, M. V., Estimation of small amounts of 0,0-diethyl 0 , p-nitrophenyl thiophosphate, Anal. Chem. 20 753-6, 1948.

2. Bratton, Calvin A., and Marshall, E. K., A new coupling component for sulfanilamide determination, J. Biol. Chem. 128 537-50, 1939.

3. Edson, E. F., Blood tests for users of O. P. Insecticides, World Crops 10 (2) 49-51, 1958.

4. Fleck, Elmer E., The residual action of organic insecticides, Ind. \& Eng. Chem. 20 706-8, 1948.

5. Gunther, Francis A., and Blinn, Roger C., Persisting insecticide residues in plant materials, An. Rev. Ent. 1 167, 1956.

6. Metcalf, Robert L., Organic Insecticides, Interscience Publishers Inc., New York, N. Y., 1955.

7. Pratt Jr., John J., and Babers, Frank H., How Insecticides Poison Insects, The Yearbook of Agriculture, USDA, 1952.

8. Shepard, H. H., The Chemistry and Action of Insecticides, McGraw-Hill Book Company, Inc., New York, N. Y., 1951. 